\title{
O EXAME CELPE-BRAS COMO POLÍTICA GATEKEEPING PARA A NATURALIZAÇÃO NO BRASIL
}

\author{
THE CELPE-BRAS EXAM AS A GATEKEEPING POLICY FOR \\ NATURALIZATION IN BRAZIL
}

\author{
Renata Franck Mendonça de Anunciação ${ }^{1}$ \\ Helena Regina Esteves de Camargo ${ }^{2}$
}

\section{RESUMo}

Neste trabalho, propomos uma reflexão sobre a política linguística que estabelece a exigência do exame Celpe-Bras em processos de naturalização e sobre as consequências que ela poderia ter no acesso ao exercício de cidadania por migrantes no país. Para tanto, analisamos tal exigência com base nos pressupostos teórico-metodológicos do Celpe-Bras (RODRIGUES, 2006; COSTA \& CARVALHO, 2013), para refletir sobre quais ideologias linguísticas (WOOLARD, 1998; MCCARTY, 2011) constituem essa nova política linguística para migração e refúgio no Brasil. Concluímos que essa exigência se configura como uma política linguística verticalizada (BIZON \& CAMARGO, 2018), racializada e assimilacionista (BLACKLEDGE, 2006; EREL et al., 2016) que reforça os processos de despossessão e de não reconhecimento (BUTLER \& ATHANASIOU, 2013) a que essas populações estão submetidas, operando como instrumento de gatekeeping (EREL et al., 2016; TRIANDAFYLLIDOU, 2014; PENNYCOOK, 1994) ou dificultando seu acesso ao exercício de cidadania.

\section{Palavras-Chave}

Migração e refúgio. Naturalização. Ideologias linguísticas. Cidadania. Celpe-Bras.

\section{Abstract}

In this paper, we propose a reflection on the linguistic policy that establishes the requirement of the Celpe-Bras proficiency exam as proof of knowledge of Portuguese in naturalization processes and on the consequences that it could have on the exercise of citizenship by migrants in the country. To do so, we analyze this requirement based on the theoretical-methodological assumptions of the Celpe-Bras exam (RODRIGUES, 2006; COSTA \& CARVALHO, 2013), to reflect on which linguistic ideologies (WOOLARD, 1998; MCCARTY, 2011) in Brazil make up this new language policy for migration and refuge. We conclude that the certification requirement represents a vertical ((BIZON \& CAMARGO, 2018), racialized and assimilationist language policy (BLACKLEDGE, 2006; EREL et al., 2016) that reinforces dispossession and non-recognition processes (BUTLER \& ATHANASIOU, 2013) to which these populations are submitted, operating as a gatekeeping instrument (EREL et al., 2016; TRIANDAFYLLIDOU, 2014; PENNYCOOK, 1994) or hindering their access to citizenship.

\section{KeYwORDS}

Migration and refuge. Naturalization; Language ideologies. Citizenship. Celpe-Bras.

\footnotetext{
1 Doutoranda em Linguística Aplicada pelo Instituto de Estudos da Linguagem - Unicamp. Leitora brasileira na Universidade Nacional Timor Lorosa'e - Timor-Leste.

2 Doutora em Linguística Aplicada pelo Instituto de Estudos da Linguagem - Unicamp. Docente no Instituto Singularidades e em rede particular de Ensino Médio.
} 


\section{INTRODUÇÃo}

De acordo com Lima [et. al.] (2017), em 2016, 65 milhões de pessoas foram forçadas a deixar seus lares, dentre as quais 21 milhões são refugiados residindo fora de seus países de nacionalidade ou de residência habitual por motivo de perseguição, ou fundado temor de perseguição, por raça, grupo social, opinião política, religião ou nacionalidade ou por decorrência de graves violações de direitos humanos.

Frente ao maior número de pessoas que foram obrigadas a migrar desde a Segunda Guerra Mundial, muitos países, sobretudo os considerados desenvolvidos, acirraram o controle de suas fronteiras ${ }^{3}$ dando continuidade a uma tendência que já vigorava, desde o 11 de setembro, de impor restrições à imigração, principalmente à imigração ilegal (FERNANDES \& FARIA, 2016). A esse fato, somam-se a participação do Brasil nos principais tratados de Direitos Humanos e em missões de paz da Organização das Nações Unidas ${ }^{4}$ e o crescimento econômico do país no período entre 2006 e 2017 (CARVALHO, 2018). A combinação desses fatores resultou na inserção do Brasil na rota das migrações Sul-Sul (BAENINGER et al, 2018). O aumento e a diversificação dos fluxos migratórios no país, com a "entrada de asiáticos, latino-americanos, haitianos e também migrantes de alta qualificação como os americanos, franceses, coreanos, espanhóis e portugueses" (BAENINGER, 2016, p. 15), instou o Brasil, que se encontrava jurídica e politicamente despreparado para receber um grande contingente de migrantes, a rever sua legislação migratória e a elaborar

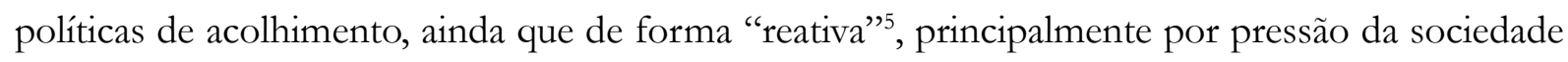
civil (PARISE, 2016).

Atualmente, o país passa por uma transição regulatória no que se refere a legislações e políticas públicas para migração, refúgio e apatridia. Aprovada em 24 de maio de 2017 e regulamentada pelo Decreto $n^{\circ}$ 9.199, de 20 de novembro do mesmo ano, a nova Lei Federal de Migração (Lei 13.445/2017) é considerada um avanço na luta por direitos igualitários entre nacionais e migrantes, uma vez que sua fundamentação nos Direitos Humanos abandona a ênfase na Segurança Nacional e na criminalização de migrantes envolvidos em atividades políticas do antigo Estatuto do Estrangeiro (Lei 6.815/1980), representando um grande avanço no tocante à proteção dos direitos dos migrantes no país (RAMOS et al., 2017). No entanto, apesar de ser mais progressista do que a lei anterior e de trazer mais celeridade aos processos de regularização migratória, os vetos presidenciais e a regulamentação conduziram a uma interpretação conservadora da nova Lei de Migração. Especificamente no que se refere à naturalização de migrantes (ordinária e especial) ${ }^{6}$, ou seja, ao desejo de obter a nacionalidade brasileira, a lei atual insere uma nova restrição: condiciona o deferi-

3 Cf. Bauman (2017) para exemplos de ações tomadas por alguns países europeus em relação ao controle da entrada de migrantes e refugiados.

4 Dentre as diversas missões de paz em que o Brasil participou desde a criação da Organização das Nações Unidas, em 1945, Baeninger e Peres (2017) destacam a presença militar brasileira no Haiti, no início do século XXI, como um dos fatores que colocou o Brasil na rota da migração haitiana após o terremoto de 2010.

5 Por reativa, Parise (2016) compreende as políticas implementadas pelo governo para prover soluções rápidas aos problemas ocasionados pela chegada em massa de migrantes que não preveem a demanda por serviços básicos, como acolhida, documentação, alimentação, amparo à saúde e cursos de língua portuguesa, para citar alguns. Um exemplo de política migratória reativa, em oposição à proativa, é a Resolução Normativa 97/2012 do Conselho Nacional de Imigração (CNIg), que dispõe sobre a concessão de visto permanente por razões humanitárias aos nacionais do Haiti.

6 A legislação brasileira estabelece que a naturalização pode ser ordinária, extraordinária, especial ou provisória. A exigência de comunicar-se em língua portuguesa, dadas as condições do naturalizando, são requisitos das naturalizações ordinária (art. 65, III) e especial (art. 69, II). Para as especificidades de cada tipo de naturalização, cf. BRASIL. Lei 13.445, de 24 de maio de 2017 . Institui a Lei de Migração. 
mento da solicitação da naturalização brasileira à aprovação no Certificado de Proficiência em Língua Portuguesa para Estrangeiros (Celpe-Bras), único exame de proficiência em Língua Portuguesa do Brasil reconhecido pelo governo brasileiro. Desde 3 de maio de 2018, o Exame Celpe-Bras passou a ser pré-requisito para migrantes que queiram se naturalizar brasileiros. A Portaria Interministerial no 11 , de 03 de maio de 2018 , que estabelece os procedimentos em relação à tramitação dos processos de naturalização (ordinária e especial), determina que a comprovação da capacidade de se comunicar em língua portuguesa, conforme as condições do naturalizando (artigos 65, III e 69, II da Lei 13.445/2017), se dará por meio da apresentação do Celpe-Bras.

Dada a relevância de se discutir a transição do marco regulatório das migrações no Brasil, propomos uma reflexão sobre a exigência do exame para comprovação de conhecimento de língua portuguesa em processos de naturalização e suas consequências ao exercício de direitos políticos dos naturalizandos. Para tanto, faz-se necessário apontar alguns aspectos da legislação brasileira que regulamenta as migrações, sendo o primeiro referente à distinção entre brasileiros natos e naturalizados?

Como regra geral e seguindo o princípio constitucional da isonomia, não há distinção legal entre brasileiros natos e naturalizados, exceto em alguns casos expressos na Constituição Federal de 1988 (REZEK, 2008; LENZA 2009): i) extradição por crime comum cometido antes da naturalização ou por tráfico ilícito de entorpecentes (CF/1988, Art. 5. $\left.{ }^{\circ}, \mathrm{LI}\right)$; ii) ocupação de cargos privativos de brasileiros natos, que são os da linha sucessória presidencial, da carreira diplomática, de oficial das Forças Armadas e de Ministro da Defesa (CF/1988, Art. 12, \3. ${ }^{\circ}$ ); iii) participação como membro do Conselho da República (CF/1988, Art. 89, VII). Assim, resguardadas as exceções acima expostas, ao migrante naturalizado brasileiro é garantido o direito de exercício de votar e ser votado (direitos políticos) e de ser servidor público.

A antiga legislação acerca da condição dos estrangeiros no Brasil, que vigorou de agosto de 1980 até maio de 2017, exigia que o naturalizando demonstrasse a capacidade de "ler e escrever a língua portuguesa, consideradas as condições do naturalizando" "BRASIL. Lei no 6.815/1980, art. 112, IV), por meio da "leitura de trechos da Constituição" (Decreto no 86.715/81, art. 129, I) para um juiz, durante a audiência. Conforme pontuam Dias e Pinto (2017), não havia um sistema de critérios comuns para fins avaliativos, tornando a avaliação discricionária. Outro aspecto do antigo sistema de avaliação criticado pelas autoras é a sua ligação a "um modelo grafocêntrico que sustenta as ideologias linguísticas do Brasil, ou seja, a ideia de que saber a língua portuguesa é saber ler e escrever nesta língua" (DIAS \& PINTO, 2017, p. 72). Acrescentamos que a exigência da língua portuguesa também valida o "mito do monolinguismo no Brasil" (CAVALCANTI, 1999, p.

\footnotetext{
7 De acordo com a legislação brasileira, existem três classificações de estrangeiros: refugiados, migrantes e apátridas. Neste artigo, consideramos as migrações que são forçadas por problemas econômicos, políticos, civis, religiosos e humanitários como "migrações de crise" (SIMON, 1995; CLOCHARD, 2007, apud BAENINGER; PERES, 2017). Bizon e Camargo (2018, p. 712) chamam a atenção para o que pode ser compreendido como o "caráter bilateral da crise" (BIZON \& CAMARGO, 2018, p. 712), indicando a presença sociohistórica da crise tanto na origem como no destino, frequentemente despreparado para receber os contingentes migratórios. Distinguimos, assim, os migrantes de crise daqueles que se deslocam para residir temporária ou permanentemente no Brasil por motivos que não evidenciam uma crise no país de origem nem uma demanda por políticas públicas de acolhimento no destino. Nesse sentido, salientamos que o termo "migrantes de crise", apesar de englobar diversas categorias migratórias, não pressupõe homogeneidade.

$8 \mathrm{O}$ Decreto $\mathrm{n}^{\circ}$ 9.199, de 20 de novembro de 2017, estabelece que "as condições do naturalizando quanto à capacidade de comunicação em língua portuguesa considerarão aquelas decorrentes de deficiência, nos termos da legislação vigente” (BRASIL. Decreto $\mathrm{n}^{\circ}$ 9.199, de 20 de novembro de 2017. Regulamenta a Lei no 13.445, de 24 de maio de 2017, que institui a Lei de Migração).
} 
3), segundo o qual a língua portuguesa é falada por todos os brasileiros, desconsiderando todas as línguas indígenas, línguas de migração, a LIBRAS e também as múltiplas variantes do português amplamente utilizadas no país. Assim, compreendemos que a publicação da Portaria Interministerial no 11 , de 03 de maio de 2018, a exigência do Celpe-Bras, exame de proficiência em língua portuguesa elaborado primeiramente para fins acadêmicos (hoje, também requerido para revalidação de diplomas de diversas categorias profissionais), contraria o caráter democrático que a nova Lei de Migrações, a princípio, pareceu demonstrar (BIZON, 2013).

Tendo discorrido sobre os aspectos legais relevantes para a discussão aqui proposta, apresentamos uma reflexão sobre a política linguística que estabelece a exigência do exame para comprovação de conhecimento de língua portuguesa em processos de naturalização e sobre as consequências que ela poderia ter no acesso ao exercício de cidadania por migrantes no país. Para tanto, analisamos tal exigência com base nos pressupostos teórico-metodológicos do exame Celpe-Bras (RODRIGUES, 2006; COSTA \& CARVALHO, 2013), para refletir sobre quais ideologias linguísticas (WOOLARD, 1998; MCCARTY, 2011) constituem essa nova política linguística para migração e refúgio no Brasil.

\section{O exame Celpe-Bras}

Completando 20 anos de criação em 2018, o Celpe-Bras é o único exame de proficiência em Língua Portuguesa do Brasil reconhecido pelo governo brasileiro. Segundo consta no Edital $n^{\circ}$ 22, de 18 de maio de 2018, o exame se destina "a estrangeiros e brasileiros, residentes no Brasil ou no exterior, cuja língua materna não seja a Língua Portuguesa”. Com o passar dos anos, ele tem se firmado como importante instrumento de política linguística nacional, ao ser exigido como pré-requisito para o ingresso de estrangeiros do Programa Estudante-Convênio Graduação (PEC-G) e do Programa Estudante-Convênio Pós-Graduação (PEC-PG), para a revalidação de diplomas de médicos formados no exterior e, em alguns casos, para a contratação de profissionais em algumas empresas privadas (COSTA; CARVALHO, 2013). Por essas razões, o Celpe-Bras é considerado um exame de alta relevância.

O exame Celpe-Bras é dividido em duas partes: a escrita e a oral. A primeira parte é composta por quatro tarefas escritas: duas de compreensão oral (cada uma realizada a partir da escuta de um áudio e de um vídeo) e duas de compreensão escrita (cada uma realizada a partir da leitura de um gênero textual diferente). O examinando deve realizar todas as tarefas propostas por meio de um enunciado formulado com base em uma situação de uso da língua.

$\mathrm{Na}$ Parte Oral, segunda parte do exame, que é individual, o candidato é avaliado por dois examinadores (pelo avaliador interlocutor e pelo avaliador observador) durante uma interação de 20 minutos. De acordo com o Edital no 22, de 17 de maio de $2018^{10}$, para obter certificação, o candidato precisa "alcançar, pelo menos, o nível intermediário nas duas Partes do Exame.”. Os níveis certificados e a pontuação necessária para obtê-los são:

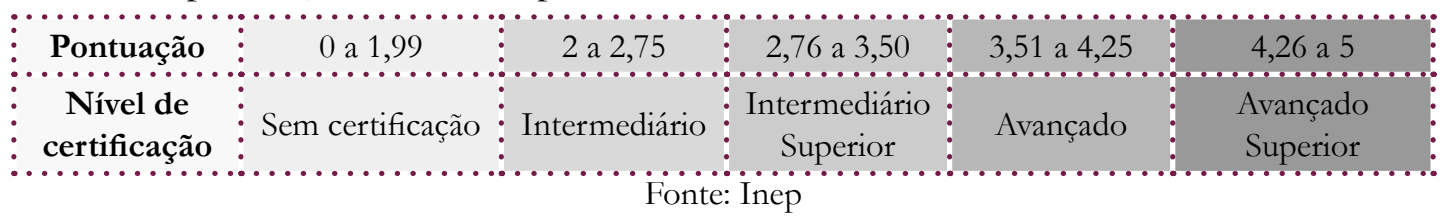

9 Como o objetivo deste artigo não é discutir sobre pressupostos teóricos-metodológicos do exame Celpe-Bras, nos permitimos descrevê-lo muito sucintamente. Para discussões mais aprofundadas sobre o exame, indicamos a leitura de Schoffen (2003), Dell'Isola, Scaramucci e Schlatter (2003), Rodrigues (2006), Costa e Carvalho (2013) e Villela, Neves e Tosatti (2017).

10 Edital $^{\circ}$ 22, de 17 de maio de 2018, publicado no Diário Oficial da União no 95, p. 56-61. 
No que se refere ao letramento exigido pelo Celpe-Bras, é relevante fazer algumas considerações. O Celpe-Bras foi concebido para avaliar diferentes níveis de conhecimento de língua a partir de um único instrumento de avaliação. O que ele avalia é a capacidade do candidato de usar a língua em diferentes contextos e situações, devido ao conceito de língua que o constitui: o de língua em uso (CLARK, 2000). De acordo com essa concepção, língua(gem) é interação, isto é, aspectos discursivos como contexto, finalidade e interlocutores são mais relevantes do que a materialidade linguística (a forma). Por essa razão, o exame não exige conhecimentos pontuais de gramática nem de vocabulário, o que se avalia é o desempenho do candidato em tarefas comunicativas orais e escritas, considerando seu nível de proficiência.

Como já foi mencionado, o exame tem sido adotado como pré-requisito para o ingresso de estrangeiros em universidades brasileiras, para validação de diplomas emitidos no exterior e até mesmo para a contratação de profissionais em empresas privadas. Assim, infere-se que o público para o qual o Celpe-Bras foi concebido esteja familiarizado com as práticas letradas que constituem o exame. Rodrigues (2006), contudo, argumenta que, apesar de a maioria dos candidatos ter um grau de instrução bastante razoável - "são médicos, engenheiros, professores" (p. 62) -, muitos têm dificuldades de realizar as tarefas propostas pelo exame, uma vez que

O candidato deve demonstrar ser capaz de compreender e produzir textos de gêneros diversos (entendendo sua organização e propósito), além de posicionar-se e relacionar ideias, adequando a linguagem a situações diversas - capacidades essas não usualmente desenvolvidas pela escola mas fundamentais para a vida das pessoas e exercício da cidadania, que dependem, antes de mais nada, de letramento e não apenas de conhecimentos sobre a língua. [...] Como esse letramento é, para muitos, inexistente até mesmo em língua materna $(\mathrm{LM})$, entendemos que o ensino em língua estrangeira teria que ser capaz de supri-lo (RODRIGUES, 2006, p. 54-55, grifo nosso).

Reafirmando o argumento apresentado por Rodrigues (2006), Costa e Carvalho (2013) apresentam uma discussão muito interessante sobre as práticas de letramento refinadas requeridas pelo exame Celpe-Bras. Para ilustrar sua argumentação, os autores analisam a tarefa IV da Parte Escrita da edição 2009/2, a partir dos critérios de avaliação do exame (adequação contextual, discursiva e linguística). Este é o enunciado da tarefa analisada por Costa e Carvalho (2013):

Você é morador da cidade de Porto Alegre e leu a reportagem 'Mesa de bar na rua opõe boêmios e insones', do Jornal Zero Hora. Com base nas informações do texto, escreva um e-mail para o vereador Alceu Brasinha, posicionando-se a favor ou contra o projeto de lei apresentado por ele.

Afirmando que os três critérios de avaliação estão interconectados, os autores destacam que os candidatos devem considerar as "características e marcas linguísticas" a partir do que é solicitado na tarefa: o enunciador (morador de Porto Alegre e leitor do Zero Hora), o interlocutor (vereador Alceu Brasinha), a ação solicitada (escrever um e-mail) e um propósito (posicionar-se contra ou a favor do projeto de lei do vereador). Costa e Carvalho (2013) salientam ainda que, para que a tarefa seja completada plenamente, é necessário que o candidato compreenda não só o enunciado da tarefa, mas também o texto de apoio (escrito por um vereador e publicado no jornal Zero Hora) e que seja capaz de fazer inferências e estabelecer relações com seu conhecimento de mundo, construindo "discursivamente seu posicionamento sobre o projeto de lei, com base nas informações 
apresentadas no texto-base" (COSTA \& CARVALHO, 2013, p. 252-253) e utilizando léxico e estruturas gramaticais adequados para a escrita de um e-mail a um vereador.

A análise feita pelos autores ilustra muito bem a questão levantada por Rodrigues (2006) e que gostaríamos de reafirmar: o exame Celpe-Bras, devido a sua concepção teórico-metodológica de avaliar competências de forma integrada a partir de textos, áudios, vídeos e imagens autênticos, simulando situações reais de uso da língua(gem), exige um conhecimento bastante apurado de práticas letradas diversas e específicas, que podem não fazer parte do cotidiano de todo naturalizando (e nem mesmo no de brasileiros. Afinal, quantos brasileiros têm o costume de escrever e-mails para vereadores sobre projetos de lei?). Preocupa-nos, portanto, que a exigência de aprovação em um exame de tão alta relevância possa se configurar como parte de uma política linguística gatekeeping, isto é, seletiva de um perfil de "migrante desejado", a exemplo das políticas migratórias do século XIX (SEYFERTH, 2008; RIBEIRO, 2015). No contexto atual, a língua portuguesa exerceria esse papel de "gatekeeper" (PENNYCOOK, 1994; BLACKLEDGE, 2006; HAMID et al. 2018) na medida em que ela, como língua hegemônica no Brasil, controla o progresso social e econômico, uma vez que "seu uso em determinadas áreas, principalmente na profissional, pode exacerbar diferentes relações de poder e pode tornar essas áreas mais inacessíveis a mais pessoas" (PENNYCOOK, 1994, p. 13).

\section{Efeitos do Celpe-Bras no ensino de PLAc}

Até a publicação da Portaria Interministerial n. 11/2018, como a obrigatoriedade do exame estava atrelada à revalidação de diplomas e à obtenção e manutenção de bolsas de estudo de graduação e de pós-graduação fornecidas por convênios entre o Brasil e outros países, os efeitos retroativos eram mais observados majoritariamente em contextos de ensino de PLA para intercambistas e trabalhadores expatriados. Evidenciamos, portanto, que a oferta de cursos preparatórios para o Celpe-Bras é restrita e não está disponível a todos os migrantes no âmbito das políticas públicas.

$\mathrm{O}$ ensino de português institucionalizado e ofertado aos migrantes de crise configura-se, como denominado por algumas autoras (CABETE, 2010; GROSSO, 2010; AMADO, 2013; BARBOSA \& SÃO BERNARDO, 2015; LOPEZ, 2016; ANUNCIAÇÃO, 2017; BIZON \& CAMARGO, 2018), como Português Língua de Acolhimento (PLAc). Destacamos que, atualmente, há duas iniciativas públicas de ensino de PLAc: o projeto "Portas Abertas: Português para Imigrantes", parceria entre a Secretaria Municipal de Educação e a Secretaria Municipal de Direitos Humanos e Cidadania de São Paulo e o projeto Português para Falantes de Outras Línguas da Secretaria de Estado de Educação do Paraná. Algumas ONGs, instituições religiosas e universidades ${ }^{11} \mathrm{em}$ cursos de extensão também ofertam o ensino de PLAc.

Em nosso entendimento, adotar o termo PLAc implica considerar o ensino de português como parte das práticas de acolhimento (ANUNCIAÇÃO, 2017) e como um dos principais direitos a elas vinculados. Em consonância com Bizon e Camargo (2018, p. 716), acreditamos que as políticas de acolhimento devem ser "pensadas e operacionalizadas multilateralmente, em um

11 Alguns exemplos de universidades que têm oferecido cursos de PLAc são: a Universidade de Brasília (UnB), a Universidade de São Paulo (USP) em parceria com a Missão Paz, instituição religiosa que acolhe imigrantes, a Universidade Federal de Minas Gerais (UFMG) e a Universidade Federal do Paraná (UFPR). 
atravessamento dos eixos vertical e horizontal (SANTOS, 2000) ${ }^{12}$ que estruturam a construção dos espaços sociais". Reconhecemos a necessidade de se institucionalizar as políticas de acolhimento para que elas passem a ser asseguradas e fomentadas pelo poder público e/ou pela iniciativa privada sem, no entanto, desconsiderar a importância de se manter o caráter de cooperação e protagonismo das microagências de todos os atores envolvidos (formuladores de políticas públicas, servidores, professores - voluntários ou não - e alunos).

Percebemos que as especificidades do PLAc, dentre as quais se destacam o contexto de migração de crise, as motivações e o tempo reduzido para o desenvolvimento linguístico e os diferentes graus de escolaridade dos migrantes (AMADO, 2014; COSTA \& SÁ, 2018), se diferem muito do contexto e das especificidades do exame Celpe-Bras. Preparar-se para o Celpe-Bras, como para qualquer exame de alta relevância, leva tempo e demanda estudo, sem contar o custo financeiro do exame. Além de esses fatores poderem representar uma dificuldade aos migrantes, é preciso atentar para a dificuldade de acesso a cursos preparatórios do exame fora dos grandes centros do país.

Reconhecemos que a perspectiva sociodiscursiva adotada pelo Exame Celpe-Bras impulsiona uma concepção de ensino/aprendizagem do português desvinculada da mera materialidade linguística (regras gramaticais) e preocupada com a formação do leitor e do escritor capaz de se posicionar criticamente em português (BIZON, 2013). Também compreendemos que seja conveniente legitimar um exame que já é reconhecido pelo governo como norteador das políticas linguísticas para o ensino de português para aqueles que não o falam como primeira língua. Contudo, não podemos ignorar que o Celpe-Bras tem sido empregado como um instrumento de seleção de indivíduos com um perfil de letramento específico em espaços de enunciação privilegiados, a saber: academia e grandes empresas. O condicionamento da obtenção da naturalização brasileira à certificação no Celpe-Bras expressa a ideia de cidadão desejável uma vez que aproxima os perfis dos candidatos ao exame, estudantes universitários, pesquisadores e trabalhadores qualificados, aos dos naturalizandos. Percebemos que esse condicionamento está embasado em ideologias linguísticas que pretendemos discutir na seção seguinte.

\section{As IDEOLOgIAS POR TRÁS dA POLÍtica linguística}

Considerando essa discussão sobre a relação entre língua, racialização e assimilacionismo, convém analisar a ideologia linguística por trás da exigência de aprovação no Exame Celpe-Bras como pré-requisito para a obtenção da nacionalidade brasileira. De acordo com McCarty, essa discussão é relevante, pois as ideologias linguísticas "contribuem para a desigualdade linguística e social” (MCCARTY, 2011, p.10), na medida em que naturalizam crenças, baseadas em senso comum, sobre o uso, as formas, o status e os falantes das línguas. Nesse sentido, pode-se afirmar que ideologias linguísticas não se referem somente a questões puramente linguísticas, mas a questões relacionadas a identidade, poder e pertencimento de indivíduos a um grupo.

12 "Segundo Milton Santos (2000), as verticalidades - ou espaço hegemônico, políticas oficiais/institucionalizadas - são representadas pelas instituições do Estado e pelas empresas [...] costumam atuar sob uma racionalidade única em que [...] ações e políticas são produzidas preponderantemente para fazer prevalecer os interesses corporativos sobre os interesses públicos. As horizontalidades ou espaço banal - são representadas pelas vivências, pelo entorno, ou seja, pelas pessoas em suas agências cotidianas [...], permitindo que as produções sejam voltadas aos interesses locais e realizadas dentro de uma área que também constitui um fator de produção" (BIZON \& CAMARGO, 2018, p. 716). 
Nesse sentido, considerando as questões identitárias, de poder e de pertencimento que constituem as ideologias linguísticas, nomeamos, a seguir, duas ideologias linguísticas interligadas que, a nosso ver, subsidiam a exigência de comprovação de proficiência em língua portuguesa por meio do Exame Celpe-Bras:

\section{Política de gatekeeping linguístico}

Com o aumento significativo do contingente de refugiados, somado ao volume total de migrantes que já procuravam condições de vida mais dignas nos países centrais, observa-se uma crescente preocupação com a segurança nacional. A tendência de interpretar os "estranhos" como assustadoramente imprevisíveis é materializada em várias formas de incerteza - "se a pessoa é aquilo que ela diz ou parece ser, quantas pessoas desse ou daquele tipo existem em um dado território, quantos deles estão entre nós" - que "criam uma ansiedade intolerável sobre o relacionamento de muitos indivíduos com os bens proporcionados pelo Estado [...] já que esses direitos estão ligados a quem 'você' é e, portanto, a quem 'eles' são”' (APPADURAI, 2006/2009, p. 16). Diferença, que pode ser tolerada ou até mesmo vista como uma contribuição ao desenvolvimento do Estado em tempos de estabilidade política e econômica, torna-se alvo de rejeição e ódio em tempos de crise, pois é interpretada como a causa da desestabilidade (APPADURAI, 2006/2009). Em vez de buscar sanar as ansiedades de seus cidadãos enfrentando as causas reais da crise, como a falta de educação de qualidade, o desemprego, a carência de assistência à saúde e de acesso à moradia digna, os governos empenham seus esforços em garantir a segurança de seu território e, consequentemente, defender os poucos bens sociais garantidos aos seus nacionais, empregando políticas de "securitização" (BAUMAN, 2017). Essa política consiste em desviar a preocupação da população com os problemas que os governos são incapazes de solucionar - ou desinteressados em fazê-lo -, para a chegada de migrantes, muitas vezes noticiada como "invasão" pela mídia, para que, assim, os governos justifiquem suas medidas para acirrar o controle das fronteiras, seja impedindo ostensivamente a entrada com muros, cercas, prisões e expulsões de migrantes, em uma política de "fencing" ", seja restringindo o acesso a direitos (sociais e/ou políticos), em uma política "gatekeeping" 14 (TRIANDAFYLLIDOU, 2014, p. 10) .

Gatekeeping são procedimentos que condicionam a entrada, a permanência, a residência, o acesso a serviços públicos e o exercício de direitos políticos e civis de estrangeiros em um território nacional ao preenchimento de critérios estabelecidos pelo Estado. São exemplos de políticas de gatekeeping uma lei estadunidense de 1882 que proibia a imigração e a naturalização de chineses em território dos Estados Unidos (LEE, 2002), o estabelecimento de cotas anuais de entrada de estrangeiros na Itália e na Grécia (TRIANDAFYLLIDOU \& AMBROSINI, 2011) e o decreto $\mathrm{n}^{\circ}$ 25.681/18, assinado em $1^{\circ}$ de agosto de 2018, pela governadora do estado de Roraima, exigindo que migrantes venezuelanos apresentassem passaportes válidos para terem acesso a serviços públicos de competência estadual.

Em consonância com alguns autores (HAMID et al., 2018; SPOT'TI, 2014; BLACKLEDGE, 2006; SHOHAMY \& MCNAMARA, 2009; MILANI, 2008; SHOHAMY, 2006), entendemos que uma prova de proficiência na língua nacional dominante se configura como instrumento de

13 Proibição de entrada em um país.

14 Seleção dos indivíduos considerados adequados e aptos a entrar e/ou permanecer em um país. 
gatekeeping linguístico, uma vez que o exercício pleno de cidadania (que inclui o direito de votar e ser votado) é condicionado à aprovação em exames que, como discutido na seção anterior, exigem um conhecimento de língua bastante apurado. Shohamy (2006) nos chama a atenção para o fato de que tal política linguística não só impede que certos grupos de pessoas sejam considerados membros da sociedade como também verifica a intenção dos migrantes de se identificarem com as ideologias nacionais e de se assimilarem. É importante apontar que a ideologia linguística que constitui a exigência de proficiência na língua oficial do país receptor para fins de naturalização se aproxima muito da ideologia de cidadania do estado-nação moderno, segundo a qual cada língua corresponde a uma nação (SHOHAMY, 2006), estabelecendo uma relação intrínseca entre língua, comunidade e território (CANAGARAJAH, 2013) em que a língua é o principal marcador da identidade nacional. Nesse sentido, Milani (2008) e Spotti (2014) argumentam que os exames de proficiência em língua para migrantes representariam mais do que "uma mensuração ou avaliação objetiva das habilidades linguísticas dos imigrantes" (MILANI, 2008, p.30), podendo ser entendidos como uma "maneira objetiva de providenciar uma prova tangível do progresso do imigrante em um contínuo que vai de 'ser estrangeiro' a 'ser um cidadão integrado”' (SPOTTI, 2014, p. 2).

\section{Política de ASsimilacionismo / Distribuição de VUlnerabilidade}

A tradicional correlação entre Estado e nacionalidade tem, historicamente, promovido políticas de assimilação cultural que silenciam práticas culturais minoritárias/minoritarizadas e impedem a participação plena de migrantes, impondo, assim, "a naturalização como pré-requisito de membresia, excluindo da cidadania uma série de status intermediários ligados à condição de migrante" (DE LUCAS et al. 2008, p. 36 apud PENCHASZADEH \& COURTIS, 2016, p. 162. Tradução nossa). Ao analisar a relação raça-migração na Grã-Bretanha atual, Erel et. al (2016) chamam a atenção para o "novo assimilacionismo" por trás da exigência de comprovação de proficiência na língua oficial do país receptor por meio de exames oficiais. De acordo com os autores, esse "novo assimilacionismo" é caracterizado pela relação intrínseca estabelecida entre racialização, migração e obtenção (e exercício) de direitos civis e políticos no país receptor.

$\mathrm{Na}$ atualidade, o assimilacionismo se daria por meio de discursos de integração em nome da coesão social, da adequação ao estilo de vida no novo país de domicílio e também no "domínio" da língua. Assim, Erel et al. (2016) explicam, ao condicionar o acesso a direitos civis e políticos à proficiência da língua oficial do país receptor, "o racismo institucional é perpetuado por meio da língua(gem) como um marcador de diferença" (EREL et al.apud, p. 1346), operando como um instrumento de distribuição de vulnerabilidade, isto é, de despossessão e de não reconhecimento (BUTLER; ATHANASIOU, 2013).

A solução para o que é considerado um problema de falta de conhecimento de língua que afeta a coesão social do país receptor acaba sendo a imposição de políticas linguísticas já ultrapassadas, "lineares e tecnocráticas (identificar o problema, formular a política, implementá-la, avaliá-la e revisá-la adequadamente)" (MCCARTY, 2011, p.6). Importa salientar que a determinação dos Ministérios foi tomada por um governo reconhecidamente conservador sem a participação da sociedade civil e sem a consulta a especialistas das áreas de avaliação e de ensino/aprendizagem de línguas, configurando-se como uma política de línguas top down. Diante disso, denunciamos o caráter tecnocrático, ahistoricizado e homogeneizante da Portaria Interministerial $n^{\circ} 11$ de 03 , de maio 
de 2018 que institui a aprovação no Exame Celpe-Bras como pré-requisito para a naturalização no Brasil, uma vez que outros agentes de políticas linguísticas que atuam nesse contexto (como pesquisadores, comunidades e coletivos de migrantes, professores de PLAc) não foram formalmente consultados acerca dessa decisão.

Por essa razão, concordamos com Penchaszadeh e Courtis (2016) quando as autoras afirmam que, nos contextos geopolítico e geoeconômico atuais, é necessário substituir a lógica tradicional cidadania-nacionalidade pela lógica cidadania-residência, contrariando o modelo de integração assimilacionista (DE LUCAS et al. 2008 apud PENCHASZADEH \& COURTIS, 2016) que "cidadaniza a naturalização", ao restringir os direitos políticos (direito de votar e de ser votado) de migrantes, alegando que a tomada de decisão em assuntos de interesse do país deve ser prerrogativa dos nacionais. Portanto, notamos que a comprovação do conhecimento da língua portuguesa nos termos do exame Celpe-Bras pode ser compreendida como um mecanismo discriminatório de seleção de cidadãos brasileiros, restringindo o acesso a direitos políticos àqueles que tiveram acesso à escolarização.

\section{CONSIDERAÇÕES FINAIS}

Compreendemos que, em tempos de grande desestabilização econômica, social, política e ambiental, com seu consequente deslocamento humano, que inseriram o Brasil na rota sul-sul dos fluxos migratórios, a obrigatoriedade de aprovação no exame Celpe-Bras, enquanto política de Estado, para obtenção da nacionalidade brasileira levanta alguns questionamentos acerca das ideologias que a constituem.

A nosso ver, condicionar o direito de obter a nacionalidade brasileira à aprovação no Celpe-Bras configura-se como uma política de gatekeeping linguístico, pois o português é empregado como uma "ferramenta opressiva e discriminatória" (SHOHAMY, 2006). Opressiva, pois impõe o conhecimento da norma padrão da língua a todos os migrantes que desejem se naturalizar, sem levar em conta os fatores que poderiam dificultar sua aprendizagem, tais como idade, grau de escolaridade, tempo de estada, os repertórios linguísticos e as práticas comunicativas em língua portuguesa em que os migrantes se envolvem. Discriminatória, pois, em um país tão cultural e linguisticamente diverso como o Brasil, o Estado, em nome da coesão social, atua como distribuidor de vulnerabilidade ao impor barreiras linguísticas que impedem que estrangeiros exerçam direitos políticos.

Reconhecemos que o conhecimento da língua oficial do país e a capacidade de expressar-se nela são cruciais para o exercício da cidadania, contudo, chamamos a atenção para o fato de que esse conhecimento não é homogêneo entre os falantes de língua portuguesa e que, por isso, um exame elaborado para fins acadêmicos não é o instrumento de avaliação de conhecimento de língua portuguesa mais adequado para o contexto de migração. Assim, condicionar a obtenção da nacionalidade brasileira a um exame que não considera as especificidades do contexto migratório nada mais é do que um tijolo a mais em um muro delimitador de fronteiras.

Diante do que foi discutido ao longo deste artigo, reiteramos nosso posicionamento enquanto pesquisadoras de políticas linguísticas para migrantes e refugiados no Brasil de que políticas linguísticas devem ser feitas para migrantes e refugiados e não para migração e refúgio. Isso implica considerar os indivíduos e as práticas sociais e linguísticas em que eles estão inseridos, ao 
legislar sobre questões que afetam diretamente seu acesso a bens e serviços públicos, bem como a sua possibilidade de exercer a cidadania plena no novo país de domicílio.

\section{REFERÊNCIAS}

AMADO, R. S. O ensino de português como língua de acolhimento para refugiados. Sociedade Internacional Português Lingua Estrangeira. 2014. Disponível em: http://bit.ly/2ZzK7EQ. Acesso: 02/08/2018.

O ensino de português como língua de acolhimento para refugiados. Revista da Sociedade Internacional Português Lingua Estrangeira, v. 4, n. 2, 2013. Disponível em: http://bit.ly/2STKZDc. Acesso em: 10 set. 2017. ANUNCIAÇÃO, R F. Somos mais que isso: Práticas de (Re)existência de Migrantes e Refugiados Frente à Despossessão e ao Não Reconhecimento. Dissertação (Mestrado em Linguística Aplicada) - Universidade Estadual de Campinas, Campinas, 2017.

APPADURAI, A. O medo ao pequeno número. Tradução: Ana Goldberger. São Paulo: Editora Iluminuras, 2006/2009.

BAENINGER, R. Migração transnacional: elementos teóricos para o debate. In: BAENINGER et al. (Orgs.). Imigração haitiana no Brasil. Jundiaí: Paco Editorial, 2016. p. 13-43.

BAENINGER, R. A.; PERES, R. G. Migração de crise: a imigração haitiana para o Brasil. Revista Brasileira de Estudos da População. Belo Horizonte, v. 34, n. 1, p. 119-143, jan./abr. 2017. Disponível em: http://bit. ly/2ZXFox6. Acesso em: 12 set. 2017.

BARBOSA, L. M. A.; SÃO BERNARDO, M. A. Português para refugiados: especificidades para acolhimento e inserção. In: SIMÕES, D. M. P.; FIGUEIREDO, F. J. Q. (Orgs.). Metodologias em/de Linguística Aplicada para ensino e aprendizagem de línguas. Campinas: Pontes, 2014, p. 269-278.

BAUMAN, Z. Estranhos à nossa porta. Tradução: Carlos Alberto Medeiros. Rio de Janeiro: Zahar, 2017.

BIZON, A. C. C. Narrando o exame Celpe-Bras e o convênio PEC-G: a construção de territorialidades em tempos de internacionalização. Tese. Doutorado em Linguística Aplicada. Campinas: Universidade Estadual de Campinas, 2013.

BIZON, A. C.; CAMARGO, H. Acolhimento e ensino da língua portuguesa à população oriunda de migração de crise no município de são Paulo: por uma política do atravessamento entre verticalidades e horizontalidades. In: BAENINGER, R; et al. (Orgs). Migrações Sul-Sul. Campinas, SP: Núcleo de Estudos de População "Elza Berquó" - Nepo/Unicamp, 2018.

BLACKLEDGE, A. The racialization of language in British political discourse. Critical Discourse Studies, v. 3, n. 01, p. 61-79, 2006.

BRASIL. Lei nº 6.815, de 19 de agosto de 1980. Define a situação jurídica do estrangeiro no Brasil, cria o Conselho Nacional de Imigração e dá outras providências. Diário Oficial da União - Seção 1 - 21/8/1980, Página 16533 (Publicação Original) Disponível em: http://bit.ly/2SRwYpt. Acesso em: 08 ago 2018.

. Constituição (1988). Constituição: República Federativa do Brasil. Brasília, DF: Senado Federal, 1988.

. Decreto $n^{\circ}$ 9.199, de 20 de novembro de 2017. Regulamenta a Lei $n^{\circ} 13.445$, de 24 de maio de 2017, que institui a Lei de Migração. Disponível em: http://bit.ly/2ZSCfyh. Acesso em 08 ago 2018.

. Senado Federal. Lei 13.445, de 24 de maio de 2017. Brasilia, 2017. Disponível em: http://bit. ly/2ZUMHWm. Acesso em: 18 jun. 2017.

Ministério da Justiça. Portaria Interministerial no 11 de 03 de maio de 2018. Dispõe sobre os procedimentos para solicitação de naturalização, de igualdade de direitos, de perda, de reaquisição de nacionalidade brasileira e de revogação da decisão de perda da nacionalidade brasileira e dá outras providências. Diário Oficial, Brasilia, DF, 04 mai. 2018, nº 85, Seção 1, p. 46.

. Conselho Nacional de Imigração. Resolução normativa no 97 de 12 de janeiro de 2012. Dispõe sobre a concessão do visto permanente previsto no art. 16 da Lei no 6.815 , de 19 de agosto de 1980, a nacionais do Haiti. 
CABETE, M. A. C. S. S. O processo de ensino-aprendizagem do português enquanto língua de acolhimento. Dissertação (Mestrado em Língua e Cultura Portuguesa). Universidade de Lisboa, Lisboa, 2010. Disponível em: http://repositorio.ul.pt/ bitstream/10451 /4090 /1/ ulfl081236_tm.pdf. Acesso em: 18 maio 2016.

CANAGARAJAH, S. Translingual practice: Global Englishes and cosmopolitan relations. Routledge, 2013.

CARVALHO, Laura. Valsa brasileira: Do boom ao caos econômico. Editora Todavia SA, 2018.

CAVALCANTI, M. C. Estudos sobre educação bilíngüe e escolarização em contextos de minorias lingüísticas no Brasil. Delta, v. 15, n. especial, 1999.

CLARK, H. O uso da linguagem. Cadernos de tradução, v. 9, p. 49-71, 2000.

CLOCHARD, O. Les réfugiés dans le monde entre protection et illégalité. EchoGéo, v. 2, 2007.

COSTA, E. V.; CARVALHO, S. C. Uso da linguagem e letramento: uma proposta de reflexão sobre a avaliação de proficiência no exame celpe-bras. Revista de Letras Norte@ mentos, v. 6, n. 12, 2013.

COSTA. E.; SÁ, E. M. PLAc, abordagem comunicativa e letramento crítico: pontos de convergência para a inclusão de práticas digitais no contexto brasileiro de ensino-aprendizagem. Letras\&Letras, v. 34, n. 1, 2018. Disponível em: http://bit.ly/2Qq4wco. Acesso: 10/08/2018.

DELL'ISOLA, R. L. P. et al. A avaliação de proficiência em português língua estrangeira: o exame CELPEBras. Revista Brasileira de Linguística Aplicada, v. 3, n. 1, p. 153-164, 2003.

DE LUCAS, M. J. et al. Los derechos de participación como elemento de integración de los inmigrantes. Reports, 2008. Disponível em: http:/ / bit.ly/36qBtuS. Acesso em 03 jun 2018.

DIAS, A. L. K.; PINTO, J. P. Ideologias linguísticas e regimes de testes de língua para migrantes no Brasil. Revista Brasileira de Linguística Aplicada, v. 17, n. 1, p. 61-81, 2017.

EREL, U.; MURJI, K.; NAHABOO, Zaki. Understanding the contemporary race-migration nexus. Ethnic and Racial Studies, v. 39, n. 8, p. 1339-1360, 2016.

FERNANDES, D.; FARIA, A. V. A diáspora haitiana no Brasil: processo de entrada, características e perfil. In: BAENINGER et al. (Orgs.). Imigração haitiana no Brasil. Jundiaí: Paco Editorial, 2016. p. 95-111.

HAMID, M. O.; HOANG, N. T. H.; KIRKPATRICK, A. Language tests, linguistic gatekeeping and global mobility. Current Issues in Language Planning, p. 1-19, 2018.

INEP. Manual do Candidato 2012 http://bit.ly/2FlgcqK. Acesso: 01 jun 2018.

GROSSO, M. J. Língua de Acolhimento, Língua de Integração. Horizontes de Linguística Aplicada. v. 9, n.2, p. 61-77, 2010. Disponível em: http:/ /bit.ly/2QoZX2a. Acesso em: 01 nov. 2015.

LEE, E. The Chinese exclusion example: Race, immigration, and American gatekeeping, 1882-1924. Journal of American Ethnic History, p. 36-62, 2002.

LENZA, P. Direito constitucional esquematizado. Editora Saraiva, 2012.

LIMA, J. B. B. et al. Refúgio no Brasil: caracterização dos perfis sociodemográficos dos refugiados (19982014). Brasília: Instituto de Pesquisa Econômica Aplicada (IPEA), 2017.

LOPEZ, A. P. A. Subsídios para o planejamento de cursos de Português como Língua de Acolhimento para imigrantes deslocados forçados no Brasil. Dissertação (Mestrado em Linguística Aplicada) - Universidade Federal de Minas Gerais, Belo Horizonte, 2016.

MCCARTY, T. L. (Ed.). Ethnography and language policy. Routledge, 2011.

MILANI, T. M. Language testing and citizenship: A language ideological debate in Sweden. Language in Society, v. 37, n. 1, p. 27-59, 2008.

OFICIAL, Diário. República Federativa do Brasil. Brasília, DF, v. 95, 2018.

PARISE, P. A Missão Paz e a acolhida a imigrantes haitianos e haitianas em São Paulo. In: BAENINGER et al. (Orgs.). Imigração haitiana no Brasil. Jundiaí: Paco Editorial, 2016. p. 409-425

PENCHASZADEH, A. P.; COURTIS, C. Sujetos politicos migrantes y el dilema de la naturalización.之 Variaciones posnacionales?. Colombia Internacional, n. 88, 2016.

PENNYCOOK, A. The cultural politics of English as an international language. New York: Longman Group Limited, 1994. 
RAMOS, A. C. et al. Regulamento da nova Lei de Migração é contra legem e praeter legem. Consultor Jurídico, 23 de novembro de 2017. Disponível em http://bit.ly/2QnrpNE. Acesso em: 26/07/2018.

REZEK, J. F. Manual de Direito Internacional Público. São Paulo: Saraiva, 2008.

RIBEIRO, D. O povo brasileiro: a formação e o sentido do Brasil. Global Editora e Distribuidora Ltda, 2015.

RODRIGUES, M. S. A. O Exame Celpe-Bras: reflexões teórico-didáticas para o professor de português para falantes de outras línguas. 2006. Dissertação. Universidade Estadual de Campinas, 2006.

SANTOS, Milton. Por uma outra globalização. Rio de janeiro: Record, v. 174, p. 25, 2000.

SEYFERTH, G. Imigrantes, estrangeiros: a trajetória de uma categoria incomoda no campo político. Trabalho apresentado na 26. Reunião Brasileira de Antropologia, 1-4 jun. 2008. Porto Seguro. Disponível em: http://bit.ly/39HzlRx. Acesso em: 21/09/2017.

SCHOFFEN, J. R. Avaliação de proficiência oral em língua estrangeira: descrição dos níveis de candidatos falantes de espanhol no exame Celpe-Bras. Dissertação. Universidade Federal do Rio Grande do Sul, 2003. SIMON, G. Géodynamique des migrations internationales dans le monde. Paris: PUF, 1995.

SHOHAMY, E. Language policy: Hidden agendas and new approaches. Routledge, 2006.

SHOHAMY, E., \& MCNAMARA, T. Language testing for citizenship, immigration and asylum [Special issue]. Language Assessment Quarterly, v. 6, n. 1, p. 1-6, 2009.

SPOTTI, M. Language testing for immigration and citizenship in the Netherlands. The companion to language Assessment. I, p. 390-403, 2013.

TRIANDAFYLLIDOU, A.; AMBROSINI, M. Irregular immigration control in Italy and Greece: strong fencing and weak gate-keeping serving the labour market. European Journal of Migration and Law, v. 13, n. 3, p. 251-273, 2011.

TRIANDAFYLLIDOU, A. Multi-levelling and externalizing migration and asylum: lessons from the southern European islands. Island Studies Journal, v. 9, n. 1, 2014.

VILLELA, A. M. N.; DE OLIVEIRA NEVES, L.; TOSATTI, N. M. Relações de poder no exame CelpeBras. Linha D’Água, v. 30, n. 1, p. 115-126, 2017.

WOOLARD, K. A. Introduction: Language Ideology as a Field of Inquiry. In: SCHIEFFELIN, Bambi B.; WOOLARD, K. A.; KROSKRITY, P. V. (Orgs.). Language ideologies: Practice and theory. Oxford University Press, 1998. 